\title{
Antropologia historii wojny i wojskowości \\ (Ch. Ingrao, Czarni myśliwi. Brygada Dirlewangera, tłum. W. Gileuski, Wydawnictwo Czarne, Wołowiec 2011, ss. 302)
}

(c) $\odot$ DOI: $10.12775 /$ KLIO.2013.009

$K^{s}$ siążka Christiana Ingrao podejmuje klasyczny temat w historii wojskoniewątpliwie klasyczna forma pisarstwa w historii wojen i wojskowości. Forma, którą, jak zauważa autor, często uznaje się za „pozytywistyczny archaizm” (s. 9). Jednocześnie jednak uważa on, że jest to forma wciąż najbardziej obiecująca, wymaga tylko przemyślenia na nowo, co też sam uczynił w prezentowanej pracy ${ }^{1}$.

W swojej monografii Ingrao zajmuje się specjalną bojową jednostką SS, utworzoną w 1940 roku przez Oskara Dirlewangera. Według francuskiego historyka w dotychczas wydanych pracach o dziejach Sondereinheit Dirlewangera nie znajdujemy analizy istoty problemu. Nie ma tam bowiem informacji na temat życia codziennego, stosunków między żołnierzami a oficerami, zmienności nastrojów, a przede wszystkim tego, co stanowi sedno wojny i działań zbrojnych, indywidualnego i zbiorowego doświadczenia przemocy (s. 11).

Przedstawiając teoretyczne zaplecze swoich analiz, badacz wskazuje na dwa „źródła” inspiracji. Jedno z nich stanowią francuskie badania pierwszej wojny światowej w kategoriach „kultury wojny” ujmującej doświadczenie, sposoby jego przeżywania, a także dotyczący go dyskurs, w tym doświadczenie wojennej przemocy, drugie to antropologia społeczna i jej narzędzia służące do opisu praktyk przemocy - „gestyki przemocy” (s. 12-13). Według niego społeczne wyobrażenie i praktykę przemocy łączy dynamiczna i sylogiczna więź, „istnienie systemu obrazów sprawia, że praktykę przemocy można sobie wyobrazić i tym samym staje się ona możliwa, a jej doświad-

${ }^{1}$ Do „nieklasycznych” monografii autor zalicza m.in. wydaną w Polsce pracę Ch. Browninga, Zwykli ludzie. 101. Policyjny Batalion Rezerwy i "ostateczne rozwiązanie” $w$ Polsce, Warszawa 2000, który w swoich interpretacjach opiera się na pracach z dziedziny psychologii społecznej oraz wynikach badań szkoły frankfurckiej, a także nawiązuje do ujęć historii oddolnej ( history from below), historii codzienności i mikrohistorii; ibidem, s. 9-15. 
czanie potwierdza status ofiar w oczach kata. [...] w gruncie rzeczy przemoc staje się swego rodzaju językiem, za pomocą którego system wyobrażeń zostaje wyrażony; staje się językiem, który ten system ujawnia” (s. 212).

W przypadku inspirowania się badaniami w perspektywie „kultury wojny" Ingrao nawiązuje do intensywnych badań we Francji historyków skupionych wokół centrum badawczego powołanego w 1989 roku i Muzeum Wielkiej Wojny otwartego w 1992 roku w Péronne². Na czele międzynarodowego zespołu stoją: Jean-Jacques Becker, Stéphane AudoinRouzeau, Annette Becker, Gerd Krumeich. Zaproponowali oni takie badanie wojny, które odnosi się do mentalnych narzędzi nadających jej sens, stosowanych przez kobiety i mężczyzn ${ }^{3}$. Wymagało to poszerzenia bazy źródłowej, wyjścia poza archiwa wojskowe i wykorzystanie dzienników wojennych i innych źródeł literackich, w tym utworów artystycznych. Tak konstruowana historia wojny i wojskowości ,ukazała ciała i psychiki, ujawniła upadki i afekty, lęki, rozterki, traumy i nienawiść oraz takie zjawiska, jak przyzwyczajenie, banalność, nuda i rozkosz" (s. 12).

Wspierając się w swoich badaniach na dorobku francuskiej antropologii społecznej lat osiemdziesiątych i dziewięćdziesiątych XX wieku, Ingrao wskazuje na takich autorów, jak Bertrand Hell, Françoise Héritier, Elisabeth Claverie, Catherine Rémy ${ }^{4}$. O roli tych etnologów w swojej pracy wspominał w jednym z udzielonych wywiadów ${ }^{5}$. Na marginesie warto

${ }^{2} \mathrm{Na}$ temat badań i dyskusji w historiografii francuskiej nad pierwszą wojną światową zob.: É. Julien, À propos de l'historiographie française de la première guerre mondiale, „Labyrinthe” 2004, t. 18, z. 2, mis en ligne le 24 juin 2008, URL: http://labyrinthe.revues. org/217, data dostępu : 08.12.2012.

${ }^{3}$ Zob.: S. Audoin-Rouzeau, A. Becker, 14-18, retrouver la guerre, Paris 1998; Histoire culturelle de la Grande Guerre, red. J.-J.Becker, Paris 2005.

${ }^{4}$ Zob.: B. Hell, Le sang noir. Chasse et mythe du sauvage en Europe, Paris 1998; F. Heritier, De la violence, t. 1, Paris 1996, idem, De la violence, t. 2, Paris 1999; É. Claverie, Les guerres de la Vierge. Une anthropologie des apparitions, Paris 2003; C. Rémy, L'espace de la mise à mort de l'animal. Ethnographie d'un abattoir, „Espaces et Sociétés”2004, nr 118, z. 3, p. 223-249. Zob. także: Sny, trofea, geny i zmarli. „Wojna” w spotecznościach przedpaństwowych na przyktadzie Amazonii - przeglad koncepcji antropologicznych, opr. T. Buliński, M. Kairski, Poznań 2006.

${ }^{5} \mathrm{~J}$. Denis, Autour de la violence de guerre. Entretien avec Christian Ingrao, „Tracés. Revue de Sciences humaines" 2008, t. 14, mis en ligne le 30 mai 2009,. URL : http://traces. revues.org/395, data dostępu 08.12.2012. 
zauważyć, że w rozmowie tej wspomina również o możliwościach wykorzystania w interesujących go badaniach psychoanalizy ${ }^{6}$.

Już na wstępie swojej pracy francuski historyk zwraca uwagę, że Sondereinheit Dirlewangera „stanowi swoiste momentum, które można by porównać ze zderzeniami cząsteczek, wywołanymi przez naukowców wewnątrz gigantycznych akceleratorów, aby ujawnić subatomową strukturę materii” (s. 14). Jego praca i jej ustalenia stanowić mają podstawę do wniosków o szerszym zakresie.

Podział na rozdziały, którego dokonał autor, sygnalizując podjęte problemy w monografii, i ich tytuły, wskazują na zasadniczą odmienność od klasycznych ujęć jednostek wojskowych w historii wojskowości. Rozdziały: Przypadek Dirlewangera, Zgoda i przymus, Ktusownicy w mieście, Wojna myśliwych?, Nowa wojna?, Okres powojenny, poza pierwszym, Historia brygady, nie zapowiadają standardowej konceptualizacji przedmiotu badań.

W swoim artykule pozwolę sobie odejść od prezentowania książki Ingrao według planu zaproponowanego przez autora. Problem dowódcy czarnych myśliwych zostanie omówiony na końcu. W pierwszej kolejności przedstawię interpretację Ingrao dotyczącą samej jednostki, w której wyjątkowo wyraźnie ujawnia się antropologiczny charakter jego analiz. Wcześniej jednak kilka słów o samym antropologizowaniu historii.

Powszechnie w literaturze pisze się o, „antropologicznej koncepcji kultury”, „ładzie antropologicznym”, „antropologicznym punkcie widzenia”. W ten sposób zakłada się, świadomie czy też nie, że mimo różnych typów argumentacji i wyjaśniania, jakie odnajdujemy w antropologii w prze-

${ }^{6}$ Monografią, w której autor posłużył się szeroko rozumianą psychoanalizą jest studium przypadku, jak pisze o swojej książce Jonathan Littell poświęconej Leonowi Degrelle’owi. Idąc za ustaleniami Klausa Theweleita, tak jak on postanawia „złapać faszystów za słowa” i podjać próbę analizy mentalnej struktury faszystowskiej osobowości, analizując wspomnienia Degrelle’a. Wartością dodaną tej analizy w stosunku do tego, co zrobił Theweleit, jest zastosowanie jego metody do materiału nie niemieckiego i do osoby, która nie poznała pierwszej wojny światowej. Zob.: J. Littell, Suche i wilgotne. Krótka wyprawa na terytorium faszysty, przeł. M. Kamińska-Maurugeon, Warszawa 2009. Dla polskiego czytelnika ciekawe może być zapoznanie się w całości ze wspomnieniami Degrelle’a, które zostały wydane po polsku, jak i porównaniu ich odczytania przez Littela z odczytaniami przez polskich komentatorów. Zob.: L. Degrelle, Front wschodni 1941-1945, przeł. D. Tararako-Grzesiak, Kraków 2007. 
szłości i teraźniejszości, możemy mówić o pewnym zespole podstawowych przesłanek i założeń, zawsze obecnych w antropologicznej konceptualizacji świata, wokół których toczyły się i toczą dyskusje określane mianem antropologicznych. Wśród nich na pierwszym miejscu znajduje się pojęcie „kultura”. Moim zdaniem jej specyficzne rozumienie wyznacza tożsamość dyskursu antropologicznego i stanowi fundament dla antropologicznej konceptualizacji świata, zatem także dla antropologii historii ${ }^{7}$. W antropologicznym „wydaniu” kultura ma globalny i całościowy charakter. Nie ma tu mowy o zawężaniu pojęcia kultury do jakiejś dziedziny życia człowieka, obejmuje ona wszystkie jego aspekty, stanowiąc przy tym kontekstową, systemową i partykularną całość. Burszta, wskazując na genezę rozumienia kultury jako całości, samodzielnej jednostki, pisze

stopniowo antropologowie, poczynając od Malinowskiego i Boasa, dochodzili do wniosku, że obserwowane przez nich [...] stany rzeczy zależne są każdorazowo od kontekstu, w którym występują, skąd może się brać w szczególności ich etniczna partykularność [...] Skonstatowano następnie, że te kontekstowe i partykularne całości formułują pewien system, w ramach którego istnieje wzajemna współzależność między jego elementami $[\ldots]^{8}$.

7 Zob.: W. Piasek, Antropologizowanie antropologizowania historii - metodologiczna refleksja nad zjawiskiem, [w:] J. Kowalewski, W. Piasek, Antropologizowanie humanistyki. Zjawisko - proces - perspektywa, Olsztyn 2009, s. 189-207. Powiązania historii i antropologii kulturowej, w zależności od lokalnych tradycji różnie zostały nazwane. Stąd mówi się dziś m.in. o historii antropologicznej, antropologii historycznej, mikrohistorii, historii codzienności, historii oddolnej, historii kulturowej itd. Za używaniem nazwy antropologia historii przemawia fakt, że „niesie w sobie [...] równoprawne otwarcie na historyków, metodologów historii, historyków historiografii, literaturoznawców i antropologów kulturowych zarazem. W języku polskim gra on bowiem na dwuznaczności terminu »historia« rozumianej raz jako res gestae, raz jako historia rerum gestarum. Dla antropologów kulturowych i metodologów historii ważniejszy jest na ogół drugi człon pola semantycznego tego słowa, dla historyków najczęściej ostatecznie pierwszy. Mieszczą się więc tu różne opcje i strategie rozpoznania historii - rozpoznania przedmiotowe oraz czynione z poziomu metajęzykowego" [Redakcja], Antropologia historii, „Rocznik Antropologii Historii” 2011, nr 1-2, s. 9.

${ }^{8}$ W. J. Burszta, Wymiary antropologicznego poznania kultury, Poznań 1992, s. 52. 
Tak rozumiane pojęcie kultury odpowiada za antropologiczną konceptualizację świata, wydaje się, że bez niej nie do pomyślenia jest antropologia, jaką znamy. Obecne jest ono zawsze w refleksji antropologicznej, niezależnie od miejsca i czasu, również współczesnej. Na przestrzeni dziejów tej dyscypliny przyjmuje jednak różne kształty w postaci jej teorii. Z tego teoretycznego dorobku od lat korzystają historycy zwracający się do antropologii. Ingrao niewątpliwie w swoich antropologicznych analizach nawiązuje do funkcjonalistycznych i kognitywistycznych antropologicznych teorii kultury.

Sondereinheit Dirlewangera powstała na polecenie Heinricha Himmlera do zwalczania zbrojnych formacji partyzanckich na tyłach frontu. $Z$ racji przeznaczenia, do oddziału postanowiono rekrutować wyłącznie skazańców przetrzymywanych w więzieniach i obozach koncentracyjnych za działalność łowiecką. Wszyscy członkowie oddziałów byli myśliwymi zajmującymi się kłusownictwem, w toku prowadzonych działań skład jednostki uległ jednak zmianie, a myśliwi stanowili tylko jedną grupę. Zagorzałymi myśliwymi byli podejmujący decyzję o powstaniu oddziału dowódcy SS z kręgów nazistowskich, poza Hitlerem, i Goering. Inicjatorzy stworzenia specjalnego oddziału z kłusowników wypowiadali się jednak bardzo spójnie na temat myśliwych i kłusowników. Wszyscy podkreślali romantyczny wymiar polowania, okrucieństwo myśliwych oraz pasję, jaka nimi kieruje. Hitler, choć odnoszący się z rezerwą do myślistwa, podkreślał jednak, że jest w nim coś romantycznego, a myśliwymi kieruje prawdziwa pasja, poza tym wskazywał na czerpanie przyjemności przez myśliwych z zadawania bólu (s. 153,155, 157). Ingrao w tym kontekście wskazuje na ustalenia Bertranda Hella, który wykazał, że na obszarach rozciągających się od Morza Śródziemnego aż po uralsko-syberyjskie stepy myśliwi i kłusownicy stanowią aspekt dyskursu interpretującego przemoc w kategoriach nastroju i gorączki.

Gorączka bierze się z nadmiaru tej „czarnej krwi”, która musi zostać przelana w czasie sezonu łowieckiego w geście przemocy łączącej zwierzę z człowiekiem. Kiedy człowiek zostaje zbyt silnie „opętany” przez czarny humor, zaczyna polować po kryjomu, poza sezonem i w ten sposób staje się kłusownikiem, a wtedy żywi się wyłącznie mięsem czerwonym lub czarnym przegrzanym. Jeśli jego pasja okazuje się zbyt silna, staje 
się cielesnym człowiekiem, Dzikusem, którego zachowanie przypomina bardziej zachowanie tropionej zwierzyny niż kogoś z kręgu domowego, ze świata ludzi, porzuconego, by móc zaspokoić swoją pasję (s. 158).

Poza tym Hell przekonuje, że ten dyskurs uosabia nie tylko postać leśnego człowieka, ale także opętanego wojownika. Stworzenie oddziału z kłusowników - z nazistowskiego punktu widzenia - oznaczało wprowadzenie Dzikusa w szeregi armii. Powołując jednostkę czarnych myśliwych, wyznaczono im jednocześnie teren działania. Skłonności kłusowników do przemocy mogły znajdować ujście w miejscach o marginalnym statusie. Tę marginalność określały topograficzne cechy terenu, który znajdował się na wschodnich kresach mocarstwa; był to obszar, na którym prowadzono wojnę przekraczającą klasyczny jej wzór - działania prowadzono przeciw wrogowi bez munduru - dzikie przestrzenie, gdzie jeszcze nie zapanowała „niemiecka cywilizacja” (s. 159-160).

Ingrao wskazuje, że odwołanie się nazistów na Wschodzie do modelu myśliwskiego pokrywa się z sytuacją militarną na tych terenach w początkach 1942 roku. Po wyprzedzeniu w tym czasie ugrupowań sowieckich przez niemiecką armię, Rosjanie zaczęli organizować się na jej tyłach. Tworzyli własne struktury na terenach wiejskich, najczęściej zalesionych, z dala od szlaków komunikacyjnych. Wcześniej, przez cały 1941 rok, partyzanci byli łapani i rozstrzeliwani na szlakach komunikacyjnych. Z początkiem 1942 roku władze niemieckie, stawiając czoło nieprzyjacielowi, „skonceptualizowały” sytuację na tyłach na wzór niemieckiej kultury myśliwskiej, oferując uczestniczącym w niej Niemcom spójny wzorzec „widzenia” i zachowań (s. 192-193).

Pierwszymi zadaniami wykonanymi przez ludzi $z$ jednostki Dirlewangera były akcje zwiadowcze, wytropienie ugrupowań partyzanckich w lasach, dokładne ich zlokalizowanie, określenie liczebności i uzbrojenia itp. Kolejne zadania, realizowane głównie w 1943 roku, związane były z przeczesywaniem terenu. Te pierwsze przypominają polowanie z podchodu, które myśliwi praktykują indywidualnie. Polega ono „na wytropieniu jelenia, podejściu go, rozpoznaniu i odczytaniu ze śladów na ziemi i roślinności, z tropu i odchodów wielkości zwierzęcia, charakteru oraz wie$\mathrm{ku}$, by potem powalić go jednym strzałem oddanym wprost $\mathrm{z}$ najbliższej odległości”. Ta forma polowania pirsch cieszyła się szczególnym uznaniem 
u Himmlera, Pohla, Bergera i innych dygnitarzy, którzy przyczynili się do powstania jednostki (s. 186). Te późniejsze zadania, wielkie operacje przeczesywania terenu, były odzwierciedleniem polowania $\mathrm{z}$ nagonką. Naganianie związane jest m.in. ze straszeniem zwierząt hałasem i zmuszaniem ich do ucieczki w kierunku linii strzelców.

Z początkiem 1942 roku wykrystalizował się także obraz wojny jako polowania i wroga jako dzikiej zwierzyny. Doskonałym przykładem przeżywania wojny jako polowania jest, zdaniem Ingrao, Kurt von Gottberg - zwierzchnik Dirlewangera. Opisując działania w ramach operacji „Nürberga”, pisał on

Wystarczyły IG 6, żeby przepędzić tych łajdaków [...]. A i tak nierzadko dawali się zabijać i palić na miejscu. Był lekki przymrozek, piękna pogoda. Doskonała na polowanie z nagonką (s. 187).

W tym czasie także wróg zaczął być postrzegany jako dzika zwierzyna. W opowieściach pojawia się figura partyzantów okaleczających żołnierzy, wyłupujących im oczy i obcinających genitalia. Według francuskiego historyka to dyskurs o tej samej treści co opowieści o szarżujących starych jeleniach lub samcach dzików kastrujących myśliwego (s. 189). Zawiera się w nim także wyobrażenie niebezpieczeństwa, jakie może spotkać myśliwego na polowaniu ze strony zwierzyny, na którą poluje (s. 197).

„Polowania z nagonką”, zwraca uwagę Ingrao, przeradzały się często w swego rodzaju „kampanie żniwne”, których celem nie było uśmiercanie i trofea w postaci broni i zabitych partyzantów, ale produkty rolne i ludzie. Jego zadaniem należy jednak widzieć je również jako łowy, są to łowy-żniwa w przeciwieństwie do łowów-zbiorów (myślistwa-zbieractwa), polowań z podchodzeniem. W przypadku tych ostatnich - w sytuacji, gdy przeczesywanie terenu generowało przemoc na skalę masową bliską rzezi, przez co wymyka się analogii polowania z nagonką - autor poszukuje modelu alternatywnego. W tych wypadkach myśliwi łowcy przemieniali się w pasterzy:

Wielkie operacje przeczesywania terenu, które przyniosły tyle cierpienia [...] miały [...] podwójny charakter. Z jednej strony Niemcy urządzali w lesie polowania na partyzantów. Z drugiej zaś - w wioskach usytuowanych na leśnych polanach pasterze ludzi zbierali żniwo pracy tych, 
których uważali za swoją trzodę. Czy podejrzewali białoruskich chłopów o wspólnictwo z dzikim, zaszytym w leśnych odstępach wrogiem? W takich sytuacjach ludność cywilna była postrzegana przez pryzmat epidemii wścieklizny i palona razem z jej domostwami podczas rzezi, która była oczyszczająca i totalna i nie miała już nic wspólnego z polowaniem, ale przypominała raczej ubój. [...] Takie podejście jest charakterystyczne dla pasterskich wyobrażeń pojawiających się w czasie epidemii (s. 220).

To, co „spina” te praktyki przemocy, polowanie i ubój, to wyobrażenie Natury, które klasyfikuje istoty żywe przestrzenie w zależności od stopnia bliskości ich powiązań ze światem Dzikusa i światem Domowników. W przypadku Domowników, ludności zamieszkującej okupowane tereny, poddanej udomowieniu, ich „powrót” do dzikości związany jest ze „skażeniem przez bandy", skażeniem wścieklizną. Jak zauważa Ingrao, św. Hubert, patron myśliwych, czczony na terenach, skąd wywodziła się większość kłusowników Dirlewangera, uważany był za leczącego wściekliznę. W ich oczach palenie wiosek i ludzi oraz dokonywane rzezie były powstrzymywaniem „powrotu Dzikusa do domowych pieleszy” (s. 219).

W 1944 roku, w wyniku inwazji Rosji na Białoruś i wycofywania się wojsk niemieckich, żołnierze Dirlewangera ostatecznie trafili do Polski, gdzie zostali skierowani do tłumienia powstania warszawskiego. Wkroczyli oni w zasadniczo inny teren niż białoruskie lasy. Pytanie, jakie w związku z tym zadaje sobie autor, to, czy wyobrażenia i praktyka łowiecka utrzymały się w czasie tłumienia powstania? Odpowiedź na to pytanie jest twierdząca. Ingrao zaznacza jednak, że niewątpliwie zmiana ta stanowiła istotną cezurę w doświadczeniu Sondereinheit.

Sposób działania oddziału nie uległ zmianie, łowieckie wyobrażenia czarnych myśliwych przekształciły powstańczą Warszawe w miejski las, w teren łowiecki. Warszawa stała się terenem ich drapieżnych łowów (s. 229). Sposób walki był taki sam, jak w walkach z partyzantami, podobnie traktowano ludność cywilną:

Czarni myśliwi - pisze Ingrao - osaczali [...] powstańców jak dziką zwierzynę i oczyszczali dymem te budynki, które stały się jej ostoją. [...] Kiedy stawali wobec ogromnych rzesz ludności cywilnej uciekającej z pola walki, traktowali ją - podobnie jak białoruskich chłopów - ni- 
czym udomowione bydło i posługiwali się takimi sposobami uśmiercania, jakich używano do uboju zwierząt rzeźnych (s. 234-235).

Zmieniając rejon łowiecki, oddział nie potrafił się jednak przystosować do przeciwnika doskonale znającego swój teren. Poza tym dowódcy przestali się troszczyć o życie swoich podwładnych. Jednostka ponosiła ogromne straty, co zresztą potęgowało wpływ wyobrażeń dotyczących animalizacji przeciwnika. Działania w Warszawie stanowiły zatem swoisty przełom w wojnie czarnych myśliwych, ale bez zerwania z wyobrażeniami, które oddziaływały na żołnierzy w Rosji (s. 234). Po sześciu tygodniach walk w Warszawie brygada została skierowana do walk na Słowacji, a następnie na Węgrzech. Nadal jej członkowie odbierali wojnę w kategoriach mentalnego uniwersum kultury myśliwych, choć prowadzone działania zbrojne miały już charakter bliski klasycznej wojnie. Na Słowacji brygada prowadziła początkowo prawdziwe operacje wojenne wymierzone przeciwko armii, a następnie działania polegające na przeczesywaniu terenu i patrolowaniu południowych i wschodnich jej obszarów. Jednym z niewielu aktów przemocy, jakich dopuścił się wtedy oddział, była egzekucja przez powieszenie cywilów w grudniu 1944 roku w wiosce Medzibrod. Jak zauważa Ingrao, większość wykonanych zdjęć z tej egzekucji ma następującą kompozycję: żołnierz pozuje przed powieszonym ciałem i dotyka go ręką. Ciała powieszonych były, jego zdaniem, wystawionymi na widok publiczny myśliwskimi trofeami. Postawa żołnierzy bowiem jest „naśladowaniem” sytuacji, kiedy to myśliwy kładzie rękę na zwierzynie położonej strzałem. Zaznacza jednocześnie, że można również odwołać się tu do mimetyki uboju, podczas którego zabite zwierzęta rzeźne są wieszane, tym bardziej że czterech powieszonych pochowano w mogilniku dla zwierząt domowych. Posłużono się tu zatem, zdaniem autora, różnorodnymi formami animalizacji Innego. Trudno jednak wskazać, która reprezentacja była tu dominująca - dzika zwierzyna łowna czy zabite zwierze domowe (s. 240).

Na Słowacji Sondereinheit Dirlewangera zostało włączone do wielkiego ugrupowania bojowego. Na Węgrzech rozmyło się w Grupie Armii „Południe”, gdzie dogłębnie zmienił się sposób wykonywania zadań przez ludzi z jednostki. Przyszło im wtedy walczyć w terenie równinnym przeciwko regularnej armii, a w ostatniej fazie walk, kiedy to sami zaczęli po- 
sługiwać się taktyką partyzantów, organizując zasadzki w celu niszczenia czołgów nieprzyjaciela, myśliwi stali się zwierzyną łowną (s. 248).

Wyobrażenia myślistwa i Dzikiego, zdaniem Ingrao, przetrwały wojnę $\mathrm{w}$ społeczeństwie niemieckim. W takich ramach analizowano po jej zakończeniu skalę przemocy jednostki Dirlewangera, marginalizując odział i jego działania. W ten sposób budowano barierę ochronną między czarnymi myśliwymi a resztą społeczeństwa, zwykłymi ludźmi. Jednostkę przedstawiano jako zbieraninę wyrzutków społeczeństwa, kryminalistów wywodzących się z najniższych warstw przedwojennego społeczeństwa, dokonujących okrutnych zbrodni. Postrzegano ich jako Dzikusów dających upust nieudomowionej, niszczycielskiej i ślepej sile. Chciano w ten sposób wytyczyć swoisty kordon sanitarny oddzielający normalne społeczeństwo niemieckie od garstki wyrzutków odpowiedzialnych za potworne zbrodnie Trzeciej Rzeszy (s. 285). Skład osobowy jednostki, który zresztą uległ zmianie - wielu nowych żołnierzy to osadzeni więzień Wehrmachtu i SS, największa ich grupa to wcieleni za przestępstwa pospolite oraz nieprawidłową postawę podczas walki - może świadczyć o tym, że jednostka nie stanowiła reprezentacji całego społeczeństwa niemieckiego. Jednakże według Ingrao przemoc $\mathrm{w}$ walce $\mathrm{z}$ partyzantami była stosowana przez wszystkich zaangażowanych w zwalczanie partyzantów, nie tylko jednostkę Dirlewangera. Biorąc pod uwagę fakt, że mamy do czynienia z jednostką bardzo ograniczoną liczebnie, nie da się uniknąć wnioskowania, że to właśnie „zwykli Niemcy” upowszechnili przemoc na frontach wschodnich, a nie margines niemieckiego społeczeństwa. To masowe zaangażowanie niemieckiego społeczeństwa wyjaśnia, dlaczego oskarżeni w powojennych procesach wspierali się dyskursem Dzikusa. Z jednej strony mamy tu do czynienia z podświadomą kontynuacją określonego dyskursu umożliwiającego konceptualizację rzeczywistości, z drugiej z gotową interpretacją zbrodni dokonywanych przez Niemców. To razem pozwalało nie tylko na negowanie faktycznej winy:

dzięki temu możliwe stało się przerzucenie nazistowskich aktów przemocy na postać Dzikusa oraz na margines społeczny, co niewielkim kosztem uwalniało od winy naród niemiecki, który w tym czasie zajmował się odbudową polityczną i gospodarczą. 
Ingrao konkluduje, że w ten sposób

Niemcy nie tylko skazywali się na wykluczenie i niezrozumienie swojej przeszłości, lecz także ponownie mobilizowali archaiczne schematy kulturowe, których tak naprawdę nie pozbyli się od czasów wilhelmińskich (s. 182).

Na koniec wróćmy do dowódcy czarnych myśliwych. Ingrao zwraca uwagę, że w powszechnej interpretacji, wpisującej się w powyżej zaprezentowane myślenie o jego oddziale, Dirlewanger to „przestępca, którego praktyki - nawet w odniesieniu do nazistowskich standardów - przekraczały wszelkie normy" (s. 81). Tymczasem według niego to jednak również produkt pewnego społeczeństwa i pewnej epoki. Dla Dirlewangera, podobnie jak dla innych Niemców, pierwsza wojna światowa, która zgotowała im tak nieszczęsny los, nigdy się nie skończyła. Niemcy przegrały ją tylko tymczasowo. Jego uczestnictwo w paramilitarnych potyczkach, rola działacza partyjnego, członka SA i NSDAP, studenta wyróżniającego się swoim volkizmem, związane były z przekonaniem, że ostateczne rozstrzygnięcie pierwszej wojny światowej wciąż jeszcze nie zapadło (s. 105). Był on jednym z wielu Niemców złączonych poczuciem groźby zniknięcia Niemiec wskutek osłabienia stratami terytorialnymi i działaniami wewnętrznych wrogów, Żydów i działaczy komunistycznych (s. 98). Postać dowódcy czarnych myśliwych to, jak pisze Ingrao:

skrajna ilustracja niezdolności niemieckiego społeczeństwa do wyjścia z pragnienia wojny, do wyzbycia się reprezentacji „świata wrogów”, którzy sprzysięgli się, żeby doprowadzić Niemcy do zguby (s. 292).

Dirlewanger to także jeden z przedstawicieli „kultury myśliwskiej”, do której należeli nazistowscy dygnitarze, którzy pierwszą wojnę światową postrzegali jako konsekwencję naruszenia tabu przez arcyksięcia zabitego w Sarajewie (s. 293). Ten bowiem zabił mityczną białą kozicę chronioną przez Salige, która stanowi odpowiedniczkę Artemidy.

W podsumowaniu swojej książki autor zwraca uwagę, że prezentowana przez niego perspektywa interpretacyjna nie podważa interpretacji, 
w których omawiane działania postrzega się jako zwieńczenie pewnego racjonalnego procesu decyzyjnego opartego na dążeniu do zapewnienia bezpieczeństwa, grabieży gospodarczej, selekcji ludności. Połączenie narzędzi z dziedziny historii społeczno-kulturowej i analizy antropologicznej, zajmującej się sferą tego, co funkcjonalne i symboliczne, umożliwia spójne ujęcie "historii odgórnej” i „historii oddolnej”. Antropologia historyczna pozwala zatem, jak pisze:

połączyć ze sobą klasyczną historiografię praktyk wojennych nazistowskiego państwa i Täterforschung, badanie zachowań obserwowanych w terenie. Pozwala zrozumieć, że tam u dołu, z perspektywy ludzi działających w terenie, operacje przeczesywania terenu miały zarazem charakter działań polegających na polowaniu na partyzantów, jak i niewoleniu i wyrzynaniu ludności cywilnej. Postrzegane z góry w oczach nazistowskich przywódców były narzędziami służącymi mobilizacji do wysiłku wojennego, ale także przemodelowaniu Europy, którą należało zgermanizować. Oddolny wizerunek wszechobecnego myśliwego dublował odgórny obraz inżyniera społecznego, statystyka, demografa, socjologa, specjalisty od kwestii rasowych (s. 300).

Wspominałem na wstępie, że zdaniem francuskiego historyka Sondereinheit Dirlewangera stanowi swoiste momentum. Prezentowana praca jest swojego rodzaju studium przypadku. Z punktu widzenia przyjętych celów, studium przypadku może mieć charakter autotelicznego lub instrumentalnego. Charakteryzując pierwszy typ studium przypadku, Robert E. Stake pisze, że

jest prowadzone wyłącznie z powodu zainteresowania przypadkiem samym w sobie. Badanie takie nie jest inicjowane ze względu na to, że wybrany przypadek jest ilustracją bądź reprezentacją szerszego zjawiska. Jego celem nie jest ani zrozumienie szerokiego i abstrakcyjnego zjawiska [...], ani budowa teorii. Wszystkie zainteresowania badacza zostają podporządkowane, przynajmniej tymczasowo, badanemu przypadkowi. Studium jest prowadzone z powodu zainteresowania określonym przypadkiem [...] i jego celem jest jego zrozumienie?

${ }^{9}$ R. E. Stake, Jakościowe studium przypadku, przeł. M. Sałkowska, [w:] Metody badań jakościowych, t. 1, red. N. K. Denzin, Y. S. Lincoln, Warszawa 2009, s. 627. Inny 
O drugim Stake zaś pisze, że odnosi się do takich badań, w których

konkretny przypadek ma służyć pogłębieniu wiedzy o szerszym zjawisku bądź wyciagnięciu bardziej ogólnych wniosków. Zainteresowanie samym przypadkiem jest drugorzędne, ma on raczej charakter wspierający i ułatwia zrozumienie czegoś innego. [...] Tutaj wybór przypadku podyktowany jest jego potencjałem dla zrozumienia innego zjawiska. Prowadząc takie studium, mamy równolegle kilka zainteresowań szczególne i ogólne ${ }^{10}$.

Stake podkreśla, że $\mathrm{z}$ racji trudności $\mathrm{w}$ wyznaczeniu granic między tymi rodzajami studiów przypadku należałoby wyróżnić „strefę studiów mieszanych" ${ }^{11}$. Jako przykład podaje studium, którego autor wskazuje, że chce zaprezentować przypadek tak, aby był interesujący sam w sobie, ale ma też inny plan, chce również dowiedzieć się czegoś na temat szerszego zjawiska ${ }^{12}$. Wydaje się zatem możliwe, obok proponowanych rodzajów studium przypadku, także mieszane studium przypadku. Takim studium byłaby monografia Ingrao. Przeprowadzana w niej analiza pozwala, zdaniem francuskiego historyka, na sformułowanie wniosku, że jeśli nawet skład oddziału „czarnych myśliwych” pozwala mówić, że była to jednostka mało reprezentatywna pod względem społecznym, to jednak stosowane przezeń praktyki przemocy ściśle odpowiadają stosowanym przez inne formacje powołane do zwalczania partyzantów. Konkluzja ta zapowiada następną książkę Ingrao, na którą warto oczekiwać ${ }^{13}$. Pisze on:

ten właśnie stan faktyczny legitymizuje, moim zdaniem, projekt globalnego badania, z wykorzystaniem podobnych narzędzi koncepcyjnych. Badanie to obejmuje metody zwalczania partyzantów na frontach wschodnich i stanie się ono tematem kolejnej książki (s. 298).

podział zob.: K. Konecki, Studia z metodologii badań jakościowych. Teoria ugruntowana, Warszawa 2000, s. 128.

${ }^{10}$ R. E. Stake, op. cit., s. 628.

${ }^{11}$ Ibidem.

${ }^{12}$ Ibidem, s. 629,

${ }^{13}$ Wydawnictwo Czarne zapowiada wydanie wcześniejszej książki Ingrao Wierzyć i niszczyć. Intelektualiśsi w machinie wojennej SS. 
Antropologia historii nie jest nową perspektywą badań w historii. W Polsce nadal jednak analizy oparte o podstawowe narzędzie antropologii społecznej i kulturowej, jakim jest kategoria kultury, z trudem przebijają się do naukowego „centrum” ${ }^{14}$. Tymczasem dzięki niej, o czym możemy się przekonać, czytając książkę Ingrao, uzyskujemy świeży i bardzo interesujący obraz zagadnień, które do tej pory ujmowane były, wydawałoby się, w jedyny możliwy sposób ${ }^{15}$.

Wojciech Piasek (Toruń)

14 W 2011 r. pod patronatem Zarządu Głównego Polskiego Towarzystwa Historycznego ukazał się pierwszy numer czasopisma „Rocznik Antropologii Historii”, którego celem jest m.in. stworzenie forum dla historyków i antropologów identyfikujących się ze stylem badań antropologii historii. Zob.: [Redakcja], Antropologia historii, „Rocznik Antropologii Historii” 2011, nr 1-2, s. 7-10; [Ankieta] Antropologia historii/ historyczna w Polsce. Pojęcia-dziedzictwo-perspektywy, ibidem, s. 233-269.

$15 \mathrm{Z}$ książek wydanych po polsku, z racji szczególnej perspektywy ujęcia zagadnienia wojskowości i wojny, warto zwrócić uwagę na artykuły, w których historia bitew w swoich analizach sięga po koncepcję pamięci. Zob.: C. Pépin, "Ich hatte einen Kamerden”: niemiecki cmentarz Wielkiej Wojny w krajobrazie francuskim, [w:] Inscenizacje pamięci, red. I. Skórzyńska, Ch. Lavrence, C. Pépin, Poznań 2007, s. 235-248; „Pamięć zaklęta w kamieniu”. Czytanie pomników ofiar Wielkiej Wojny w Québecu (1919-1939) jako miejsce pamięci, [w:] ibidem, s. 259-268; P. Vennant, Braki w pamięci, czy pamięć w nietadzie? Rzecz o upamiętnianiu wojny $w$ Québecu, [w:] ibidem, s. 269-276. Zob. także prace autorów niezwiązanych z ośrodkami naukowymi: S. Aleksijewcz, Wojna nie ma nic z kobiety, przeł. J. Czech, Wołowiec 2011; P. Englunda, Piękno i smutek wojny. Dwadzieścia niezwyktych losów z czasu światowej pożogi, przeł. E. Fabisiak, Kraków 2011. Pierwsza książka przedstawia „inną wojnę”. Dzięki wspomnieniom kobiet, uczestniczek drugiej wojny światowej, poznajemy tę wojnę w doświadczeniu kobiet. We wstępie drugiej książki autor pisze „Jest to książka o pierwszej wojnie światowej. Nie jest to jednak opowieść o tym, co to była za wojna - czyli o jej przyczynach, przebiegu i skutkach - lecz książka o tym, jaka była ta wojna. A zatem znajdą tu państwo raczej człowieka niż fakty, raczej wrażenia, przeżycia i nastroje niż procesy wojenne. Chodziło mi o rekonstrukcję świata uczuć, a nie przebiegu działań wojennych”, P. Englunda, op. cit., s. 9. 